\title{
EGF effects on p53 in MDA-468 human breast cancer cells: implications for $\mathbf{G}_{1}$ arrest
}

\author{
K. A. N. Prasad and J. G. Church \\ Terry Fox Cancer Research Laboratories, Division of Basic Medical Sciences, Faculty of Medicine, \\ Memorial University of Newfoundland, St John's, Newfoundland, Canada
}

(Received 15 January 1997; revision accepted 8 June 1997)

\begin{abstract}
EGF, in pharmacological concentrations, inhibits cell proliferation of the MDA-468 human breast cancer cell line. Previously, we have demonstrated that this was characterized by a reversible cell cycle arrest at the $\mathrm{G}_{1}-\mathrm{S}$ boundary, concomitant with downregulation of mRNA levels for p53 (a point mutant, p53 $3^{273 . H i s}$ ). Since $\mathrm{p} 53^{273 . \mathrm{His}}$ is regarded as a gain-of-function mutant and acts to enhance cell proliferation, we hypothesized that the $G_{1}$ arrest induced by EGF might be mediated by p53 $3^{273.4 i s}$. In this study, we report an EGF-dependent altered conformation as indicated by immunofluorescence, while no significant immediate effects of EGF-treatment on ${\mathrm{p} 53^{273 . H i s}}^{2}$ protein levels and synthesis were observed. These experiments demonstrated a decreased PAb 240 (mutant-specific) reactivity of nuclear p53 $3^{273 . \mathrm{His}}$ in EGF-treated cells, while that of PAb 1620 (wild-type specific) was enhanced. Staining with PAb 1801 (pan specific), on the other hand, showed little change upon EGF treatment. Further studies indicated a decreased phosphorylation of nuclear p53 $3^{27.3 . H i s}$ in EGF-treated cells. These EGF-dependent events were detected early enough to be attributed as causative of cell cycle arrest. We suggest that EGF-mediated, phosphorylation-dependent conformational change in nuclear $\mathrm{p} 53^{273 . \mathrm{His}}$, and in turn altered $\mathrm{p} 53$ function, may be responsible for EGF-dependent growth inhibition MDA-468 cells.
\end{abstract}

Functional alteration of tumour suppressor p53, either by association with viral proteins, or by mutations is critical for cellular transformation in many human tumours (Levine \& Momand 1990, Hollstein et al. 1991, Levine et al. 1991). p53 regulates entry of cells into $S$ phase and progression of DNA replication in both normal and transformed cells (Deppert et al. 1990, Shaulsky et al. 1990, Steinmeyer et al. 1990, Levine et al. 1991). Consistent with this, nuclear localization of p53 in normal fibroblasts is observed prior to $G_{1} / S$ transition and during $S$ phase but not in mitosis (Shaulsky et al. 1990). The ability of p53 to either induce cell cycle arrest or promote transformation could be determined by its conformation. A temperature-sensitive mutant $\mathrm{p} 53$ protein, $5^{53^{135} \text {. Val }}$, was transforming in conjunction with ras at $37^{\circ} \mathrm{C}$ (mutant conformation $\mathrm{PAb} 240$ reactive), but suppresses transformation at $32.5^{\circ} \mathrm{C}$ (wild-type form, PAb 246 reactive) by inducing a late $\mathrm{G}_{1}$ arrest (Ginsberg et al. 1991b, Martinez et al. 1991, Michalovitz et al. 1991). Cell cycle regulation by p53 operates in late $\mathrm{G}_{1}$ phase, prior to the restriction point ( $\mathrm{R}$ point (Lin et al. 1992)). In normal and tumour cells,

Correspondence: Dr K. A. Nagendra Prasad, Department of Biology, Miorrill Science Center, University of Massachusetts, Amherst, MA 01003, USA. 
loss of p53 function abrogates a check-point in late $G_{1}$ which is thought to be responsible for maintaining genomic integrity following DNA damage (Kuerbitz et al. 1992, Harvey et al. 1993, Tsukada et al. 1993).

MDA-468 human breast cancer cells contain an amplified EGF receptor gene leading to overexpression of EGF receptors $\left(\sim 1.5 \times 10^{6}\right.$ receptors/cell $)$ with characteristics similar to those for normal cells (Filmus et al. 1985, Filmus et al. 1987). While EGF in physiological (picomolar) concentrations is mitogenic, pharmacological (nanomolar) concentrations were shown to inhibit cell proliferation of MDA-468 cells (Filmus et al. 1985, Church \& Buick 1988). We have earlier demonstrated that EGF-mediated growth inhibitory effect was characterized by a reversible $G_{1}$ arrest accompanied by a decreased level of mRNA for p53 (Prasad \& Church 1991). MDA-468 cells contain a single allele for p53 with a point mutation at codon 273 (p53 $3^{27.4 i s}$ ) resulting in substitution of arginine by histidine (Nigro et al. 1989, Bartek et al. 1990). p53 $3^{27.3 i s}$ is more analogous to wild-type p53 in terms of ability to bind SV40 $\mathrm{T}$ antigen, to transactivate heterologous promoters when expressed as a GAL4 fusion protein and to react with wild-type specific antibody PAb 1620 (Bartek et al. 1990, Ginsberg et al. 1991a, Milner et al. 1987). However, p53 $3^{273 . \text { His }}$ has a longer half-life (>7-8 h), reacts with mutant specific antibody, PAb 240, and most interestingly, possess transforming potential in co-operation with activated ras (Hinds et al. 1990; reviewed in Levine et al. 1991, Michalovitz et al. 1991). p53 $3^{273.4 i s}$ has reduced non-specific DNA binding and fails to bind some sequences that are recognized by wild-type p53, but retains the ability to transactivate through a consensus sequence identified by Funk et al. (1992) (Bargonetti et al. 1991, Kern et al. 1991, Funk et al. 1992). Thus, while wild-type p53 is regarded as a negative regulator of cell proliferation, there exists a definite possibility that some of the transforming mutants of $\mathrm{p} 53$, such as $\mathrm{p} 53^{273 . \mathrm{His}}$, remain active, inducing the expression of genes essential for cell cycle progression.

Indeed, several studies have indicated a role for $\mathrm{p} 53^{273 . \text { His }}$ in proliferation and tumourigenicity of MDA-468 cells. These studies demonstrated that exogenously introduced wildtype p53 abolished the focus formation ability and tumourigenicity of MDA-468 cells (Casey et al. 1991, Wang et al. 1993). On the other hand, downregulation of $\mathrm{p} 53^{273.4 i s}$ levels by a flavonoid compound, quercetin, resulted in cell cycle arrest (Avila et al. 1994). These and the observation that EGF-treated MDA-468 cells displayed lower levels of mRNA for a mutant p53 suggested that p53 may play a role in growth inhibition. To examine this possibility and to understand the molecular mechanism involved, we initiated an analysis of EGF effects on p53 in MDA-468 human breast cancer cells, including protein synthesis, steady state protein levels, sub-cellular localization, and phosphorylation status of $\mathrm{p} 53$.

\section{MATERIALS AND METHODS}

\section{Antibodies used}

The following mouse monoclonal antibodies against p53 were obtained from Oncogene Science (Manhasset, NY). PAb 1801 (Ab 2), a human-specific antibody, reactive with both wild-type and mutant p53 (Banks et al. 1986), PAb 240 (Ab 3), a mutant-specific and conformation-dependent antibody (Gannon et al. 1990), and PAb 421 (Ab 1), a mammalian p53-specific antibody reactive with both wild-type and mutant forms of p53 (Harlow et al. 1981). PAb 1620, human wild-type p53-specific antibody (Milner et al. 1987), was provided as a gift from Dr Heinz-Kurt Hoechkoppel, Ciba-Geigy, Switzerland. A mouse monoclonal antibody, IgG2a, raised against an MHC antigen (a gift from Dr G. Carayanniotis, Memorial University of Newfoundland, Canada), was used as the antibody control in Western blot, 
immunoprecipitation and immunofluorescence experiments. Fluorescein isothiocyanate (FITC)-conjugated anti-mouse, F(ab)'2-specific IgG, for use in immunofluorescence was obtained from Jackson Immunochemicals/Bio-Can Scientific, Missisauga, Ontario, Canada.

\section{Cell culture}

MDA-468, a human breast cancer cell line, was maintained in Leibovitz-15 modified medium (ICN/Flow) supplemented with 10\% FBS (ICN/Flow and Gibco Labs), $50 \mathrm{IU} / \mathrm{ml}$ penicillin and $50 \mu \mathrm{g} / \mathrm{ml}$ streptomycin (ICN/Flow). Cells were routinely grown in $100 \mathrm{~mm}$ plates and or $75 \mathrm{~cm}^{2}$ flasks. A concentration of $1 \times 10^{-8} \mathrm{M}$ of EGF (Collaborative Res. Inc.) was employed in our studies. It has been demonstrated by seveal groups that this concentration $\left(1 \times 10^{-8} \mathrm{M}\right)$ of EGF produces optimum growth inhibition (Gill \& Lazar 1981, Barnes 1982, Lifshitz et al. 1983, Filmus et al. 1985, Filmus et al. 1987).

\section{Western blot analysis}

Subconfluent cells were treated with EGF $\left(1 \times 10^{-8} \mathrm{M}\right)$ for 0 to $48 \mathrm{~h}$ followed by trypsinization. After washing once with PBS, cells were resuspended with cell homogenization buffer (20 mм Tris/HCl (pH 7.4), 5 mм EGTA, I $\mu \mathrm{g} / \mathrm{ml}$ leupeptin, $10 \mu \mathrm{g} / \mathrm{ml}$ aprotinin, $1 \mathrm{~mm}$ phenylmethylsulfonylfluoride (PMSF)) (all from Sigma, Oakville, Ontario, Canada). Cell suspensions were then subjected to five cycles of ultrasonification ( $30 \mathrm{sec}$ on and $30 \mathrm{sec}$ off) on ice. Complete cell lysis was confirmed by microscopic examination. Protein concentrations were then determined by Lowry's colourimetric assay (Lowry et al. 1951). One hundred micrograms of total protein was run on an $8 \%$ SDS-PAGE, transferred to nitro-cellulose (Optibind, Mandel Sci. using a semi-dry transfer method (Hoefer/Fischer Sci. Ltd, Ontario, Canada). The nitro-cellulose filter was incubated overnight in $10 \%$ dried milk membrane blocking agent at $4^{\circ} \mathrm{C}$ with constant rotation. Western blot analysis was then performed with PAb 1801, followed by an alkaline-phosphatase detection system as per the manufacturer's instructions (Amersham, Oakville, Ontario, Canada). The primary anti-p53 antibody, PAb 1801 was used at $10 \mu \mathrm{g} / \mathrm{ml}$ and the second antibody, biotinylated goat anti-mouse IgG, was used at $1: 250$ dilution.

\section{Immunofluorescence experiments}

Cells were grown on chambered glass slides with serum containing media under conditions described in the figure legend (Figure 1). At the indicated intervals, monolayers were washed three times with PBS, and fixed with a methanol:acetone $(1: 1)$ mixture at $-20^{\circ} \mathrm{C}$ for $10 \mathrm{~min}$. After fixing, slides were either air dried and stored at $-70^{\circ} \mathrm{C}$ or stained immediately. Cells were washed three times with PBS and blocked with $3 \%$ bovine serum albumin in PBS (PBS/BSA) for $30 \mathrm{~min}$ at room temperature. After rinsing three times with PBS, cells were incubated at RT for 60 min with either a control antibody (anti-MHC) or an anti-p53 antibody (PAb 1801 or PAb 240) at $5 \mu \mathrm{g} / \mathrm{ml}$ concentration in PBS/BSA. After three washes with PBS, slides were stained with fluorescein isothiocyanate (FITC)-conjugated anti-mouse $\operatorname{IgG}\left(\mathrm{F}(\mathrm{ab})^{\prime} 2\right.$ specific) at 1:50 dilution in $\mathrm{PBS} / \mathrm{BSA}$ for $30 \mathrm{~min}$ at room temperature. Following staining, cells were washed extensively with PBS followed by a final rinse with double distilled water, mounted with $50 \%$ glycerol and observed under a fluorescent microscope. Photographs were taken using Kodak Ektachrome $400 \mathrm{film}$. For PAb 1620 staining, cells were prepared essentially in an identical manner except that blocking was carried out with $3 \% \mathrm{PBS} / \mathrm{BSA}$ at $37^{\circ} \mathrm{C}$. For the experiments with aphidicolin $(5 \mu \mathrm{g} / \mathrm{ml}$ final concentration; Sigma), cells were treated for $24 \mathrm{~h}$ prior to fixing. 

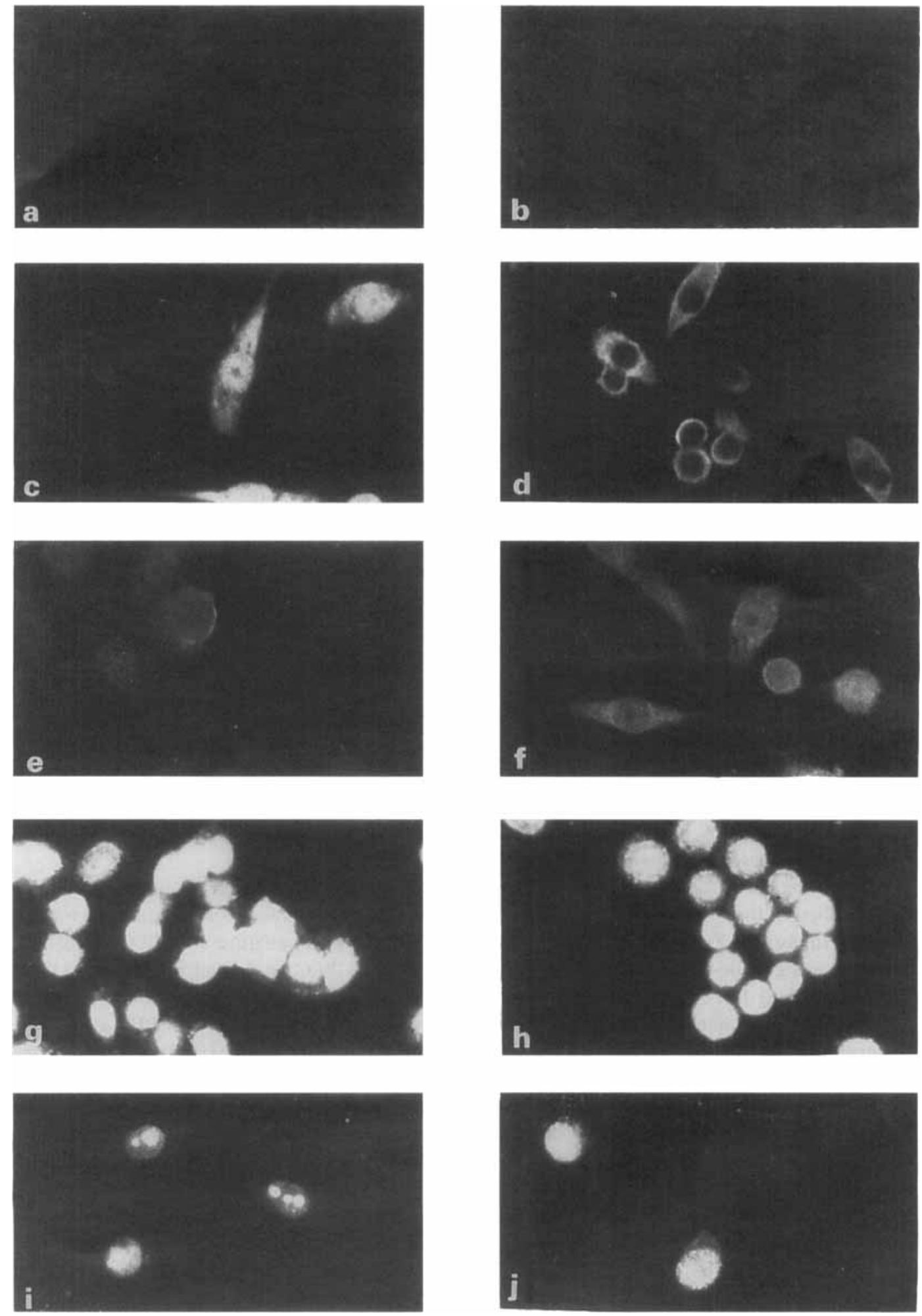

(O) 1997 Blackwell Science Ltd, Cell Proliferation, 30, 81-94. 


\section{Metabolic labelling}

Cells $\left(1 \times 10^{6}\right.$ cells $/ 100 \mathrm{~mm}$ plates $)$ cultured $+/-$ EGF $\left(1 \times 10^{-8} \mathrm{M}\right)$ for indicated durations, were labelled with $3.7 \mathrm{MBq} / \mathrm{ml}{ }^{35} \mathrm{~S}$-methionine in methionine-free medium or $\mathrm{H}_{3}\left({ }^{32} \mathrm{P}\right) \mathrm{O}_{4}$ ((carrier free; specific activity $10555 \mathrm{GBq} / \mathrm{mg}$ ) ICN, Montreal, Canada) in phosphate-free DMEM media with $20 \mathrm{~mm}$ Hepes $(\mathrm{pH} 8.0)$ during the last $2 \mathrm{~h}$ of incubation prior to harvesting. At the end of the labelling period, cells were washed three times with ice-cold PBS followed by scraping with $10 \mathrm{~mm}$ EDTA ( $\mathrm{pH} \mathrm{8.0)}$ in PBS. Cells were pelleted by centrifugation at $800 \mathrm{~g}$ at $4^{\circ} \mathrm{C}$. Nuclear extract from these cells were prepared as detailed below. For phosphorylation experiments (Figure 3c), cells $\left(1 \times 10^{6}\right.$ cells $/ 100 \mathrm{~mm}$ plates) were incubated with $9.26 \mathrm{MBq} / \mathrm{ml}$ of $\left.\mathrm{H}_{3}{ }^{32} \mathrm{P}\right) \mathrm{O}_{4}$ in phosphate-free DMEM media with $20 \mathrm{~mm}$ Hepes $(\mathrm{pH} 8.0)$ during the final $3 \mathrm{~h}$ of epidermal growth factor (EFG) treatment. At the end of labelling, cells were lysed and immunoprecipitated using the appropriate antibody as described below.

\section{Immunoprecipitation from nuclear extracts}

The cell pellet was resuspended in buffer $(20 \mathrm{~mm}$ Hepes $(\mathrm{pH} 7.6), 20 \%$ glycerol, $0.5 \mathrm{M} \mathrm{NaCl}$, $1.5 \mathrm{~mm} \mathrm{MgCl}, 0.2 \mathrm{~mm}$ EDTA, $0.1 \%$ Triton X-100, $1 \mathrm{~mm}$ DTT, $10 \mu \mathrm{g} / \mathrm{ml}$ leupeptin, $100 \mu \mathrm{g} / \mathrm{ml}$ aprotinin, $1 \mathrm{~mm}$ PMSF (Lassar et al. 1991)) at $50 \mu \mathrm{l} / \mathrm{pellet}$ from each $100-\mathrm{mm}$ plate. The suspension was gently rocked at $4^{\circ} \mathrm{C}$ for $1 \mathrm{~h}$ followed by centrifugation at $10000 \mathrm{~g}$ for $5 \mathrm{~min}$ at $4^{\circ} \mathrm{C}$. The supernatant was subjected to scintillation counting. Equivalent counts in $40 \mu \mathrm{l}$ volume (volume adjusted with buffer), from each sample of extracts (see below), were incubated with $350 \mu \mathrm{l}$ of nuclear extract immunoprecipitation buffer $(10 \mathrm{~mm}$ Hepes ( $\mathrm{pH} 7.6)$, $250 \mathrm{~mm} \mathrm{NaCl}, 0.25 \% \mathrm{NP}-40,5 \mathrm{~mm}$ EDTA, $10 \mu \mathrm{g} / \mathrm{ml}$ leupeptin, $100 \mu \mathrm{g} / \mathrm{ml}$ aprotinin, $1 \mathrm{~mm}$ PMSF (Lassar et al. 1991), $1.0 \mu \mathrm{g}$ of anti-p53 antibody (PAb 1801) and $25 \mu \mathrm{l}$ of $50 \%$ protein A-Sepharose. The incubation was carricd out at $4^{\circ} \mathrm{C}$ for $90 \mathrm{~min}$ with gentle rocking. The immunoprecipitates were then recovered by centrifugation at $10000 \mathrm{~g}$ for $2 \mathrm{~min}$ at $4^{\circ} \mathrm{C}$. The Sepharose pellet was washed four times with RIPA buffer ( $10 \mathrm{~mm}$ Tris. $\mathrm{HCl}(\mathrm{pH} 7.4), 150 \mathrm{~mm}$ $\mathrm{NaCl}, 1 \% \mathrm{NP}-40,0.5 \%$ sodium deoxycholate, $0.1 \%$ SDS, $10 \mu \mathrm{g} / \mathrm{ml}$ leupeptin, $100 \mu \mathrm{g} / \mathrm{ml}$ aprotinin, $1 \mathrm{~mm}$ PMSF (Lassar et al. 1991)). The samples were then boiled with SDS digestion buffer for $5 \mathrm{~min}$ and centrifuged. The supernatant was separated on a $10 \%$ SDS-PAGE. The gels were dried at $80^{\circ} \mathrm{C}$ for $1 \mathrm{~h}$ and exposed to Kodak XAR film at $-70^{\circ} \mathrm{C}$

\section{Immunoprecipitation from whole cell lysates}

Cells were washed twice with PBS before harvesting. $\mathrm{H}_{3}\left({ }^{32} \mathrm{P}\right) \mathrm{O}_{4}$ labelled cells were harvested by scraping with $0.5 \mathrm{ml}$ lysis buffer $(50 \mathrm{~mm}$ Hepes $(\mathrm{pH} 7.5), 150 \mathrm{~mm} \mathrm{NaCl}, 10 \%$ glycerol, $1 \%$ Triton X-100, $1.5 \mathrm{~mm} \mathrm{MgCl}, 1 \mathrm{~mm}$ EDTA, $10 \mu \mathrm{g} / \mathrm{ml}$ leupeptin, $10 \mu \mathrm{g} / \mathrm{ml}$ aprotinin, $1 \mathrm{~mm}$

Figure 1. Immunofluorescent studies on sub cellular localization of p53 in response to EGF. MDA-468 cells cultured under conditions indicated below for varying durations. Cells were fixed with methanol/ acetone $(1: 1)$, blocked with $3 \%$ BSA/PBS, and incubated with the anti-p53 antibodies $(5 \mu \mathrm{g} / \mathrm{ml})$ followed by staining with FITC-conjugated anti-mouse immunoglobulin (1:50). The p53 localization was detected by fluorescent microscopy at $\times 40$ magnification. Panels $a, b, c, g$ and $i$ are control/untreated cells; panels $\mathrm{d}, \mathrm{h}$ and $\mathrm{j}$ are $24 \mathrm{~h} \mathrm{EGF}\left(1 \times 10^{*} \mathrm{~m}\right)$-treated cells; panel e, $24 \mathrm{~h}$ after EGF was withdrawn from $48 \mathrm{~h}$ EGF-treated cells; panel f, cells trcated with aphidicolin $(5 \mu \mathrm{g} / \mathrm{ml})$ for $24 \mathrm{~h}$. Primary antibodies: panels a, secondary antibody alone, panel $b$, control antibody, panels $c$ to $f$, PAb 240 (mutant-specific): panels $g$ and $h$, PAb 1801 (pan-specific); and panels $i$ and $\mathrm{j}$, PAb 1620 (wild-type specific). 
PMSF, $200 \mu \mathrm{m} \mathrm{Na} \mathrm{VO}_{4}, 10 \mathrm{~mm} \mathrm{Na} \mathrm{P}_{2} \mathrm{O}_{7} 10 \mathrm{H}_{2} \mathrm{O}, 100 \mathrm{~mm} \mathrm{NaF}$ (Margolis et al. 1989) for $30 \mathrm{~min}$ on icc, and centrifuged $30 \mathrm{~min}$ at $10000 \mathrm{~g}$ in a microfuge at $4^{\circ} \mathrm{C}$. The supernatant was recovered and treated with $1 \mu \mathrm{g}$ of p53 antibody (PAb 1801) for at least $1 \mathrm{~h}$ at $4^{\circ} \mathrm{C}$ followed by $30 \mu \mathrm{l}$ of $50 \%$ protein A-Sepharose (Amersham) with rotation at $4^{\circ} \mathrm{C}$. The immunoprecipitates were then recovered by centrifugation for $30 \mathrm{~s}$ at $10000 \mathrm{~g}$, washed three times with $0.5 \mathrm{ml}$ of wash buffer $(20 \mathrm{~mm}$ Hepes $(\mathrm{pH} 7.5), 10 \%$ glycerol, $0.1 \%$ Triton X-100, $150 \mathrm{~mm}$ $\mathrm{NaCl}, 1 \mathrm{~mm} \mathrm{Na} \mathrm{VO}_{4}$ (Margolis et al. 1989)) followed by a final wash in PBS and resuspension in $30 \mu$ of ten times SDS-digestion buffer. The samples were then boiled for $5 \mathrm{~min}$, pelleted, and the supernatant was recovered and electrophoresed on SDS-PAGE. The samples were always adjusted for equal radioactivity. Experiments in which sample standardization was done based on equal cell numbers yielded similar results. At the end of electrophoresis, gels were dried, and autoradiographed using Kodak XAR film at $-70^{\circ} \mathrm{C}$.

\section{RESULTS}

\section{Western blot analysis}

The effect of growth inhibitory concentrations of EGF on 553 protcin levels was examined by Western blot analysis using a human-specific antibody, PAb 1801. In addition, EGF effect on p53 protein synthesis was investigated by immunoproecipitation of p53 with PAb 1801, after brief metabolic labelling of cells with ${ }^{35} \mathrm{~S}$-methionine. Although immunoprecipitation experiments indicated marked downregulation of p53 synthesis by 3-6 h (data not shown), Western blot analysis revealed little alteration in steady state levels for $\mathrm{p} 53$ protein even after $24 \mathrm{~h}$ of EGF treatment (Figure 2, lanes 3 to 8). However, after $48 \mathrm{~h}$ of EGF treatment, p53 protein levels were considerably lower compared to untreated cells (Figure 2, lanes 9 and 10).

\section{Immunofluorescence studies}

The cellular site of action for p53, a transcription factor, is nuclear. Hence, we examined the sub-cellular localization of p53 in MDA-468 cells, in cycling and EGF-treated conditions. To this end, we made use of three anti-p53 antibodies in immunofluroescence studies as detailed in the Materials section. All these antibodies are known to react with the p53 protein in MDA-468 cells in immunoprecipitation procedures to various extents, and to produce a strong cellular staining in immunofluorescence reactions (Milner et al. 1987, Bartek et al. 1990).

In control untreated cells, antibodies PAb 240 and PAb 1801 displayed a characteristic nuclear signal along with generalized cytoplasm staining (Figures $1 \mathrm{c}$ and $\mathrm{g}$ ). However, the addition of EGF to the media elicited differential staining patterns with the two antibodies. With PAb 1801, EGF treatment did not significantly alter the nuclear signal (Figures $2 \mathrm{~g}$ and h). The cells were examined for up to $72 \mathrm{~h}$ in the presence or absence of EGF, and no significant shifts in the intracellular distribution were observed during this period (data not shown). On the other hand, PAb 240, a mutant-specific antibody, weakly detected nuclear signals in EGF-treated cells while continuing to produce strong signals in the cytoplasm (Figure 1, compare d with $\mathrm{c}$ ). This intriguing lack of nuclear staining became apparent as early as $6 \mathrm{~h}$ post-EGF treatment in about $25 \%$ to $30 \%$ of cells and was observed in $70 \%$ to $75 \%$ of the population within $24 \mathrm{~h}$ of EGF treatment. Untreated control cells continued to display the characteristic nuclear signal along with cytoplasmic staining (Figure 1c).

Withdrawal of EGF from the media after $48 \mathrm{~h}$ of EGF treatment resulted in re-appearance of nuclear signal in 18-24 h (Figure 1e) consistent with the previously observed resumption of DNA synthesis following EGF withdrawal and the reversible nature of the cell cycle arrest 


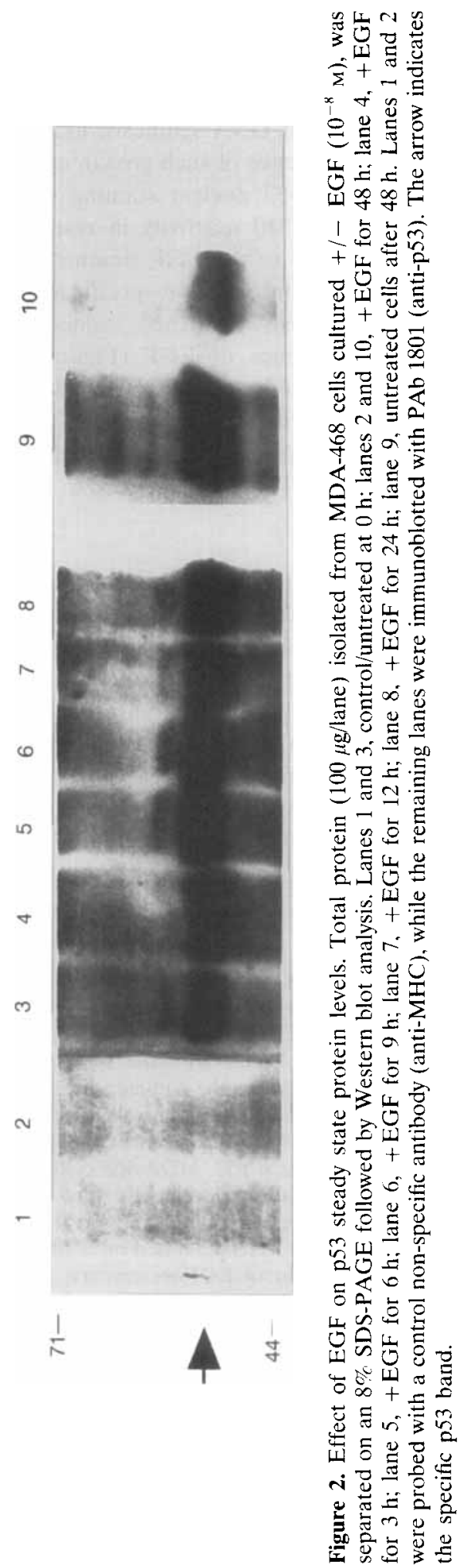

(C)1997 Blackwell Science Ltd, Cell Proliferation, 30. 81-94. 
(Prasad \& Church 1991). To test whether this alteration in staining pattern with PAb 240 is specific to EGF or is an indirect result of growth inhibition, another $G_{1}$ arrest-inducing agent, aphidicolin, was employed. Aphidicolin is a specific inhibitor of DNA polymerase- $x$ and induces a late $G_{1}$ block in the cell cycle. In MDA-468 cells, treatment with aphidicolin $(5 \mu \mathrm{g} / \mathrm{ml})$ for $24 \mathrm{~h}$ resutled in an $80 \%$ drop in DNA synthesis, indicating that a majority of cells were cell cycle arrested. Immunofluroescence of such growth arrested cells with PAb 240 did not reveal any significant shift in the p53 nuclear staining apttern (Figure 1f). This observation confirmed that the loss of PAb 240 reactivity in response to EGF was not a non-specific reaction to $G_{1}$ arrest but specific to the EGF treatment.

We wished to determine whether another conformation-specific antibody, PAb 1620, would react with the nuclear p53 in EGF-treated cells. PAb 1620, stained nuclei and in particular the nucleoli with high intensity in the absence of EGF (Figure 2i) as reported earlier (Slingerland et al. 1993). EGF treatment did indeed cause an increase in overall nuclear staining (Figure 1j). Taken together, the immunofluorescence data demonstrated that EGF-treated cells continued to carry nuclear p53 that is reactive with PAb 1801 and more so with PAb 1620 but not with PAb 240.

\section{Phosphorylation studies}

The immunofluorescence data indicated an EGF-induced shift in the conformation of nuclear p53, or, alternatively, decreased nuclear translocation of a population of p53 molecules that are reactive with PAb 240. Protein phosphorylation is believed to be a molecular mechanism that may mediate both altered protein conformation and nuclear translocation (Addison et al. 1990, Barford 1991). Therefore, the effect of EGF on the phosphorylation status of p53 was studied. $\mathrm{H}_{3}\left({ }^{32} \mathrm{P}\right) \mathrm{O}_{4}$-labelled nuclear extracts were immunoprecipitated with PAb 1801 (Figure 3a). Interestingly, nuclear p53 was phosphorylated to a lesser extent upon EGF-treatment compared to that from untreated cells. Phosphorylation of p53 was about $65 \%$ of control, within $2 \mathrm{~h}$ of EGF addition (Figure 3a, compare lanes 3 and 4 ): it was $43 \%$ of control (lanes 5 and 6 ) and about $30 \%$ of control after 4 and $6 \mathrm{~h}$ of EGF

Figure 3. (a) Effect of EGF on phosphorylation of nuclear p53. MDA-468 cells $\left(1 \times 10^{6}\right.$ cells $/ 100 \mathrm{~mm}$ plate) were treated with $+/-\operatorname{EGF}\left(1 \times 10^{-8} \mathrm{M}\right)$ for the indicated periods. Nuclear extracts from $\mathrm{H}_{3}\left({ }^{32} \mathrm{P}^{2} \mathrm{O}_{4}(9.26 \mathrm{MBq} / \mathrm{ml}\right.$ for the final $2 \mathrm{~h}$ of EGF treatment) labelled cells were used for immunoprecipitation with PAb 1801 (lanes 2-8) or control antibody (lane 1) and were separated on a $10 \%$ SDS-PAGE. Lanes 1 and $2,0 \mathrm{~h}$ (labelled for $2 \mathrm{~h}$ prior to the commencement of EGF-treatment); lanes 3,5 and 7 , untreated, corresponding to $2 \mathrm{~h}, 4 \mathrm{~h}$ and $6 \mathrm{~h}$ controls, respectively; lancs 4,6 and 8 , EGF-treated $2 \mathrm{~h}, 4 \mathrm{~h}$ and $6 \mathrm{~h}$, respectively. The arrowhead indicates the specific band corresponding to p53. (b) Effect of EGF on nuclear de nov synthesized p53. MDA-468 cells $\left(1 \times 10^{6}\right.$ cells $/ 100 \mathrm{~mm}$ plate $)$ were treated with EGF $\left(1 \times 10^{-8} \mathrm{M}\right)$ for the indicated periods. Cells were labelled with ${ }^{35} \mathrm{~S}$-methionine $(3.7 \mathrm{MBq} / \mathrm{ml})$ during the final $2 \mathrm{~h}$ of EGF-treatment. Immunoprecipitates from the nuclear extracts with PAb 1801 (lanes 2-8) and control antibody (lane 1) were separated on a 10\% SDS-PAGE. Lanes 1 and 2, $0 \mathrm{~h}$ (labelled for $2 \mathrm{~h}$ prior to the commencement of EGF-treatment); lanes 3, 5 and 7, untreated, corresponding to $2 \mathrm{~h}, 4 \mathrm{~h}$ and $6 \mathrm{~h}$ controls, respectively; lanes 4,6 and 8, EGF-treated $2 \mathrm{~h}, 4 \mathrm{~h}$ and $6 \mathrm{~h}$, respectively. The arrowhead indicates the specific band corresponding to p53. (c) Effect of EGF on p53 phosphorylation. MDA-468 cells $\left(1 \times 10^{6}\right.$ cells $/ 100 \mathrm{~mm}$ plate $)$ were treated with EGF $\left(\times 10^{-8} \mathrm{M}\right)$ for the indicated periods. Cells were labelled with $\mathrm{H}_{3}\left({ }^{32} \mathrm{P}\right) \mathrm{O}_{4}(9.26 \mathrm{MBq} / \mathrm{ml})$ for the final $3 \mathrm{~h}$ of EGF treatment. Immunoprecipitates with PAb 1801 (lanes 2-5) and control antibody (lane 1) were separated on a $10 \%$ SDS-PAGE. The arrowhead indicates the specific band corresponding to p53. Lanes 1 and 2, control/ untreated $3 \mathrm{~h}$; lane 4, control/untreated $6 \mathrm{~h}$; lanes 3 and 5, EGF-treated $3 \mathrm{~h}$ and $6 \mathrm{~h}$, respectively. (d) Comparative laser densitometric scanning analysis of panels $a, b$ and $c$. $\square$, total extract $-{ }^{32} \mathrm{PO}_{4}$ (c); $\square$, nuclear extract $-{ }^{32} \mathrm{PO}_{4}(\mathrm{a})$; and $\mathbf{m}$, nuciear extract $-{ }^{35} \mathrm{~S}(\mathrm{~b})$. 
treatment, respectively (lanes 7 and 8 ), as revealed by the laser densitometric scanning analysis (Figure 3d).

To test whether EGF induces a block in nuclear translocation, p53 immunoprecipitations with PAb 1801 from nuclear extracts prepared from cells labelled with ${ }^{35} \mathrm{~S}$-methionine during the last $2 \mathrm{~h}$ of EGF-treatment were performed. The results (Figure $3 \mathrm{~b}$ ) demonstrated no significant differences in the nuclear content of newly synthesized, and therefore labelled, p53

(a)

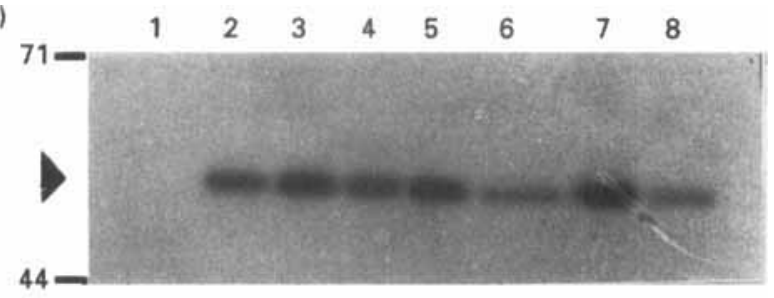

(b)

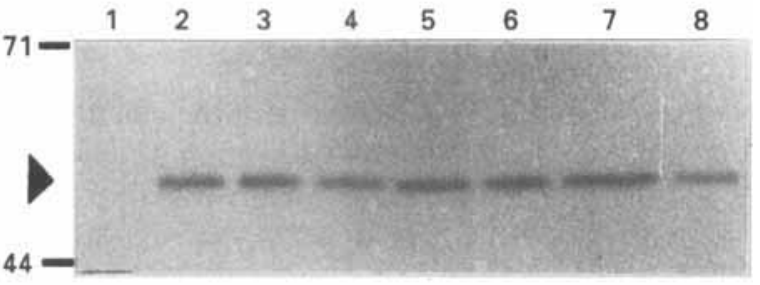

(c)

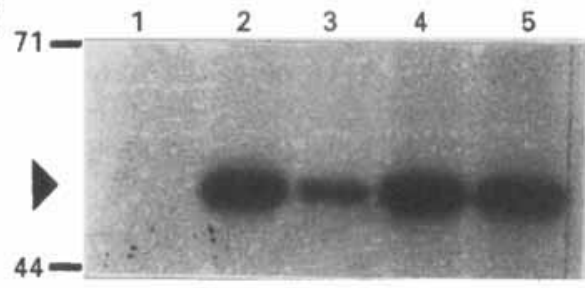

(d)

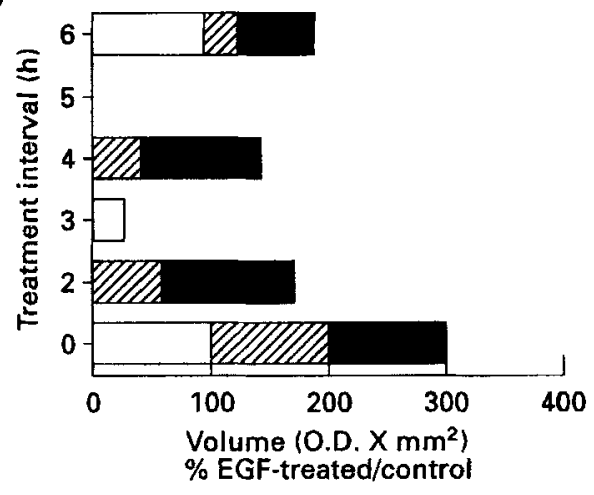

(C)1997 Blackwell Science Ltd, Cell Proliferation, 30. 81-94. 
protein up to $4 \mathrm{~h}$ after EGF-treatment. We interpret this to indicate no significant changes in the nuclear translocation of the newly synthesized p53 in the presence of EGF. After $6 \mathrm{~h}$ of EGF treatment, there was a decrease in the nuclear translocation of newly synthesized p53 (which was about $60 \%$ of control), where as phosphorylated p53 levels were much lower at the same interval of EGF treatment (about $30 \%$ of control) indicating that the differences observed with the phosphorylation of p53 were significant (Figure 3d).

Metabolic labelling of cells with $\mathrm{H}_{3}\left({ }^{32} \mathrm{P}\right) \mathrm{O}_{4}$ and subsequent immunoprecipitation of p53 from wholc cell extracts with PAb 1801 also revealed significant differences in the phosphorylation levels of p53 in response to EGF (Figure 3c). EGF caused a dramatic reduction in p53 phosphorylation within $3 \mathrm{~h}$ to about $25 \%$ of control (Figure $3 \mathrm{c}$, lanes 2 and 3 ), however, at $6 \mathrm{~h}$ post-treatment, EGF-treated cells displayed similar p53-32 $\mathrm{P}$ content (about $86 \%$ of control) as compared to untreated control cells (Figure 3c, lanes 4 and 5). This may be due to increased phosphorylation of cytoplasmic p53 protein masking the changes in nuclear p53. Increased phosphorylation of cytoplasmic p53 further indicates that the cellular kinases in general are not inactivated in the presence of EGF and that overall cellular phosphorylation is not affected in response to EGF.

\section{DISCUSSION}

We have previously characterized EGF-mediated growth inhibition in MDA-468 cells as a reversible $G_{1}$ arrest (Prasad \& Church 1991). Observation of lowered mRNA levels for p53 in EGF-treated cells and the documented $G_{1}$ regulatory role of $p 53$, led us to hypothesize an involvement of 553 in EGF-mediated $\mathrm{G}_{1}$ arrest. MDA-468 cells are homozygously deleted for another tumour suppressor, the retinoblastoma gene $(\mathrm{Rb})$ and harbour a single allele for p53 with a point mutation at codon 273 (Nigro et al. 1989, Bartek et al. 1990). Therefore, it seemed quite conceivable that loss of negative regulation by $\mathrm{Rb}$ and wild-type $\mathrm{p} 53$, together with an added dominant oncogenic function of the persistent mutant p53 allele, may be driving the cell cycle of MDA-468 cells. Several studies did indeed underscore the importance of p53 in the cell cycle progression of MDA-468 cells (Casey et al. 1991, Wang et al. 1993, Avila et al. 1994). This portion of the study was initiated to investigate the possibility of p53 being the target for EGF in MDA-468 cells.

We have earlier observed downregulation of mRNA levels for p53 after about $18-24 \mathrm{~h}$ of EGF treatment (Prasad \& Church 1991). However, an immediate EGF effect observed in MDA-468 cells was reduced overall protein synthesis, which was maximum within $12 \mathrm{~h}$ of EGF-treatment (Prasad \& Church, unpublished observation). Therefore, the observed EGF-effect on p53 mRNA levels is unlikely to constitute a cause for growth inhibition. Our experiments indicate little alteration in p53 protein levels in response to EGF up until $24 \mathrm{~h}$ (Figure 2). This was a reasonable observation considering the apparent over-expression and longer half-life $(7-8 \mathrm{~h}$ ) of mutant p53 (Hinds et al. 1990). These results make it clear that any change in p53 judged a putative cause of growth inhibition must then be post-translational and would be expected to reverse the function of the native p53 protein. Here we report that such a change is reflected in an altered antibody-reactivity to nuclear p53, as detected by a mutant-specific antibody, PAb 240, in response to EGF (Figures 1c and d). Lack of PAb 240 nuclear staining occurs early enough to be attributed as causative, and is reversible upon withdrawal of EGF (Figure 2e). Moreover, this obsevation is specific to EGF-treatment and not a non-specific result of cell cycle arrest as indicated by immunofluorescence of aphidicolin-treated cells (Figure 2f). Considered alone, this might simply be interpreted as a block in nuclear translocation of mutant 553 by EGF, thereby removing an essential driving force 
for cell cycle progression. However, detection of nuclear p53 with PAb 1801 in EGF-treated cells raised an important question as to whether or not p53 so detected was in the wild-type conformation, being non-reactive with mutant-specific PAb 240. Indeed, nuclear p53 was recognized and detected by a wild-type specific antibody, PAb 1620, in untreated cells and the staining was enhanced in EGF-treated cells (Figures $2 \mathrm{i}$ and j). Intriguingly, PAb 1620 stained preferentially the nucleoli in untreated cells with only faint staining of the rest of the nucleus. In EGF-treated cells, however, increased staining of the entire nucleus was apparent. It was clear that in EGF-treated cells, nuclear p53 retains only a wild-type specific (detected by PAb 1620) epitope and not a PAb 240 reactive one.

These observations led us to hypothesize a molecular mechanism that may be responsible for EGF-induced growth inhibition in MDA-468 cells. EGF clearly induces a change in the conformation of nuclear p53, leading to decreased amounts of p53 molecules expressing the mutant-specific epitope. MDA-468 cells may therefore contain p53 molecules capable of two distinct conformations, both mutant and wild-type-like, despite the presence of a single, genotypically mutant allele. Evidence for the existence of two distinct populations of p53 in MDA-468 cells is inconclusive. PAb 240 reacts weakly with $\mathrm{p} 53^{273 . \text { His }}$ in immunoprecipitation experiments. While $\mathrm{p} 53^{273 . \mathrm{His}}$ is reactive with the wild-type specific antibody, PAb 1620, sequential immunoprecipitation from nuclear extracts, in our hands, failed to bring down detectable amounts of protein with conformation-specific antibodies (both PAb 1620 and PAb 240), perhaps due to the higher salt concentrations employed for preparation of nuclear extracts. Alternatively, $\mathrm{p}^{273 . \mathrm{His}}$ in MDA-468 cells may be in a distinct or unique conformation. This may explain its peculiar properties. $\mathrm{p} 53^{273 .+\mathrm{Hin}}$ might retain its wild-type conformation, as recognized by PAb 1620, but may also have an altered conformation relevant to other epitopes. This might result in a poorly recognizable PAb 240 epitope. The observed differences in PAb 240 immunofluorescence could be an indication of further change in the conformation of $\mathrm{p} 53^{273 . \mathrm{His}}$. However, loss of PAb 240 reactivity might have occurred simply as a result of epitope masking due to post-translational modifications such as phosphorylation. We do not think this is the case however, since EGF-treated cells demonstrated reduced, not increased, p53 phosphorylation, although we have no detailed information on the sites that are affected. Moreover, p53 can be immunoprecipitated from whole cell extracts with PAb 240, albeit poorly, from both untreated and EGF-treated cells. Although, we were unable to confirm either a 'two distinct population theory' or a 'unique distinct conformation theory', data reported here indicate that EGF is clearly tilting the balance of p53 conformation from mutant-like to more wild-type-like. However, DNA binding studies using p53 from MDA-468 cells and 553 responsive DNA sequences, provided clues in support of existence of conformationally distinct populations with unique DNA binding properties (Prasad \& Church 1997). More studies are clearly needed to understand the molecular and functional interaction of p53 molecules and biological consequences.

This type of phenomenon is not altogether unprecedented. Evidence in support of an apparent conformational flexibility of wild-type p53 can be found as long as 12 years ago (Milner 1984) and confirmation has been accumulating in the literature over the past few years (Milner 1991, Milner \& Medcalf 1991. Ullrich, Mercer \& Appella 1992, Zerrahn et al. 1992, Fiscella et al. 1993, Halazonetis et al. 1993, Halazonetis \& Kandil 1993, Ullrich et al. 1993). These studies, based on immunoreactivity of p53 molecules, were further strengthened by the knowledge gained by crystal structure of p53-DNA complexes (Arrowsmith \& Morin 1996). These studies suggest a possible partial folding of mutant p53 molecules thereby exposing PAb 240 cpitope. In wild-typc molecules, however, PAb 240 epitope is cryptic because of extensive folding. Further, it was suggested that in a given cell p53 can remain in 
both forms of alternate protein folding. Two forms can be interchanged based on the cellular environment. Protein folding can be altered by external factors such as temperature changes, phosphorylation, or interaction with other cellular proteins (Arrowsmith \& Morin 1996). Indeed, work from several laboratories has convincingly demonstrated that phosphorylation plays an important role in regulating p53 function (Ullrich, Mercer \& Appella 1992, Ullrich et al. 1992, Fiscella et al. 1993, Ullrich et al. 1993). Interestingly, our experiments indicated a considerable reduction in the levels of $\mathrm{p} 53$ phosphorylation upon EGF treatment (Figure 3). This, coupled with no changes in p53 protein levels as indicated by the Western blot analysis (Figure 2) and by ${ }^{35} \mathrm{~S}$-methionine labelled cell immunoprecipitations from nuclear fractions (Figure $3 \mathrm{c}$ ), suggest that the decreased phosphorylation of $\mathrm{p} 53^{273.4 i s}$ is significant.

In light of this, our observations are important for two reasons. First, our evidence suggests conformational flexibility for a p53 mutant, where a dynamic equilibrium between two conformations in the nucleus would determine the $G_{1}-S$ progression. Second, this is one of the few studies linking a growth factor signal transduction pathway to a biological role for p53. EGF-dependent signalling is envisioned to shift the p53 conformation equilibrium towards the growth suppressing wild-type form thereby inhibiting cell cycle progression. Consistent with this notion is our recent observation that MDA-468 cells carry functionally distinct populations of 553 molecules that are conformationally different (Prasad \& Church 1997). Further studies are ongoing to identify the possible kinases involved in this EGF-induced phenomenon in order to delineate underlying molecular pathways leading to $\mathrm{G}_{1}$ arrest.

\section{ACKNOWLEDGEMENTS}

The authors are thankful to Dr Ron Buick, Ontario Cancer Institute, Toronto, Canada, for the MDA-468 cell line, and to Professor Michel Kazatchkine and Dr Srini Kaveri, INSERM U430, Paris, France, for their help in putting this manuscript together. Drs Narasimha Swamy, Rakesh Mittal and Umesh Kumar are acknowledged for helpful discussion. This work was supported in part by Grant MT010936 from the Medical Research Council of Canada, and Grants 1965 and 3907 from the National Cancer Institute of Canada to J.G.C.; K.A.N.P. was a recipient of a National Cancer Institute of Canada Steve Fonyo Predoctoral Research Fellowship.

\section{REFERENCES}

AdDison C, Jenkins JR, Sturzbecher HW. (1990) The p53 nuclear localisation signal is structurally linked to a p34cdc2 kinase motif. Oncogene 5, 423.

Arrowsmith CH. Morin P. (1996) New insights into p53 function from structural studies. Oncogene 12. 1379.

Avir.a MA, Velasco JA, Cansado J, Notario V. (1994) Quercetin mediates the down-regulation of mutant p53 in the human breast cancer cell line MDA-MB468. Cancer Res. 54, 2424.

Banks L, Matlashewski G, Crawford L. (1986) Isolation of human-p53-specific monoclonal antibodies and their use in the studies of human p53 expression. Eur. J. Biochem. 159, 529.

BARFord D. (1991) Molecular mechanisms for the control of enzymic activity by protein phosphorylation. Biochim. Biophys. Acta 1133, 55.

Bargonetti J, Friedman PN, Kern SE, Vogelstein B, Prives C. (1991) Wild-type but not mutant p53 immunopurified proteins bind to sequences adjacent to the SV40 origin of replication. Cell 65 , 1083.

BARNES DW. (1982) Epidermal growth factor inhibits growth of A431 human epidermoid carcinoma in serum-free cell culture. J. Cell Biol. 93, 1. 
Bartek J, IgGo R, Gannon J, Lane DP. (1990) Genetic and immunochemical analysis of mutant p53 in human breast cancer cell lines. Oncogene 5, 893 .

Casey G, Lo-Hsueh M, Lopez ME, Vocieistisin B, Standridgie EJ. (1991) Growth suppression of human breast cancer cells by the introduction of a wild-type p53 gene. Oncogene 6, 1791.

Church JG, Buick RN. (1988) G-protein-mediated epidermal growth factor signal transduction in a human breast cancer cell line. Evidence for two intracellular pathways distinguishable by pertussis toxin. J. Biol. Chem. 263, 4242.

Deppert W, Buschhaushen DG, Patschinsky T, Steinmeyer K. (1990) Cell cycle control of p53 in normal (3T3) and chemically transformed (Mcth A) mouse cells. II. Requirement for cell cycle progression. Oncogene 5, 1701.

Filmus J, Pollak MN, Cailleau R, Buick RN. (1985) MDA-468, a human breast cancer cell line with a high number of epidermal growth factor (EGF) receptors, has an amplified EGF receptor gene and is growth inhibited by EGF. Biochem. Biophys. Res. Comm. 128, 898.

Filmus J, Trent JM, Pollak MN, Buick RN. (1987) Epidermal growth factor receptor gene-amplified MDA-468 breast cancer cell line and its nonamplified variants. Mol. Cell Biol. 7, 251.

Fiscella M. Uillrich SJ, Zambrano N et al. (1993) Mutation of the serine 15 phosphorylation site of human p53 reduces the ability of p53 to inhibit cell cycle progression. Oncogene $8,1519$.

Funk WD, Pak DT, Karas RH, Wright WE, ShaY JW. (1992) A transcriptionally active DNA-binding site for human p53 protein complexes. Mol. Cell Biol. 12, 2866.

Gannon JV, Greaves R, Iggo R, Lane DP. (1990) Activating mutations in p53 produce a common conformational effect. A monoclonal antibody specific for the mutant form. EMBO. J. 9, 1595 .

Gili. GN, Lazar CS. (1981) Increased phosphotyrosine content and inhibition of proliferation in EGF-treated A431 cells. Nature 293, 305.

Ginsberg D, Mechta F, Yaniv M, Oren M. (1991a) Wild-type p53 can down-modulate the activity of various promoters. Proc. Natl. Acad. Sci. USA 88, 9979.

Ginsberg D, Michael MD, Ginsberg D, Oren M. (1991b) Induction of growth arrest by a temperature-sensitive p53 mutant is correlated with increased nuclear localization and decreased stability of the protein. Mol. Cell Biol. 11, 582.

Halazonetis TD, Davis LJ, Kandil. AN. (199.3) Wild-type p53 adopts a 'mutant'-like conformation when bound to DNA. EMBO. J. 12, 1021.

Halazonetis TD, Kandu. AN. (1993) Conformational shifts propagate from the oligomerization domain of 553 to its tetrameric DNA binding domain and restore DNA binding to select p53 mutants. EMBO. J. 12. 5057.

Harlow E, Crawford LV, Pim DC, Williamson NM. (1981) Monoclonal antibodies specific for simian virus 40 tumor antigens. J. Virol. 39. 861.

Harvey M. SAndS AT, Weiss RS et al. (1993) In vitro growth characteristics of embryo fibroblasts isolated from p53-deficient mice. Oncogene 8. 2457.

Hinds PW, Finaly CA, Quartin RS et al. (1990) Mutant p53 DNA clones from human colon carcinomas cooperate with ras in transforming primary rat cells: a comparison of the "hot spot' mutant phenotypes. Cell Growth Differ. 1, 571.

Hollstein M, Sidransky D, Vogelstein B, Harris CC. (1991) p53 mutations in human cancers. Science 253, 49.

Kern SE, Kinzler KW, Baker SJ et al. (1991) Mutant p53 proteins bind DNA abnormally in vitro. Oncogene 6, 131.

Kern SE, Kinzler KW. Bruskin A et al. (1991b) Identification of p53 as a sequence-specific DNA-binding protein. Science 252, 1708.

Kueribitz SJ, Pl.unketr BS, Walsh WV, Kastan MB. (1992) Wild-type p53 is a cell cycle checkpoint determinant following irradiation. Proc. Natl. Acad. Sci. USA 89, 7491.

Lassar AB, Davis RL, Wright WE et al. (1991) Functional activity of myogenic HLH proteins requires hetero-oligomerization with E12/E47-like proteins in vivo. Cell 66, 305.

Levine AJ, Momand J. (1990) Tumor suppressor genes: the p53 and retinoblastoma sensitivity genes and gene products. Biochim. Biophys. Acta 1032, 119.

Levine AJ, Momand J, Fint.ay CA. (1991) The p5,3 tumour suppressor gene. Nature 351, 453.

Lifshitz. A, Lazar CS, Buss JE, Gull GN. (1983) Analysis of morphology and receptor metabolism in clonal variant A431 cells with differing growth responses to epidermal growth factor. J. Cell Physiol. $115,235$.

Lin D, Shields MT, Ul.lrich SJ, Appel. E, Mi:rcer WE. (1992) Growth arrest induced by wild-type 
p53 protein blocks cells prior to or near the restriction point in late G1 phase. Proc. Natl. Acad. Sci. USA 89, 9210.

Lowry OH, Rosebrough NJ, Fakr AL, Randall RJ. (1951) Protein measurement with the folin phenol reagent. J. Biol. Chem. 193, 265.

Margolis B, Rhee SG, Felder S et al. (1989) EGF induces tyrosine phosphorylation of phospholipase C-II: a potential mechanism for EGF receptor signaling. Cell 57, 1101.

Martinez J, Georgoff I, Martinez J, Levine AJ. (1991) Cellular localization and cell cycle regulation by a temperature-sensitive p53 protein. Genes Dev: 5, 151.

Michalovitz D, halevy O, Oren M. (1991) p53 mutations: gains or losses? J. Cell Biochem. 45, 22.

MuINER J. (1984) Different forms of p53 detected by monoclonal antibodies in non-dividing and dividing lymphocytes. Nature 310, 143.

MiLner J. (1991) The role of p53 in the normal control of cell proliferation [published erratum appears in Curr. Opin Cell Biol. 1991 Jun; 3(3): following 5741. Curr Opin Cell Biol 3, 282.

Milner J, Cook A, Sheldon M. (1987) A new anti-p53 monoclonal antibody, previously reported to be directed against the large $T$ antigen of simian virus 40. Oncogene 1, 453.

Milner J, Medcalf EA. (1991) Cotranslation of activated mutant p53 with wild type drives the wildtype p53 protein into the mutant conformation. Cell 65, 765.

Nigro JM, Baker SJ. Preisinger AC et al. (1989) Mutations in the p53 gene occur in diverse human tumour types. Nature 342, 705.

Prasad KA, Church JG. (1991) EGF-dependent growth inhibition in MDA-468 human breast cancer cells is characterized by late G1 arrest and altered gene expression [published erratum in Exp. Cell Res. 1991: 196(2): 365]. Exp. Cell Res. 195, 20.

Prasad KA, Church JG. (1997) Characterisation of DNA binding and transcriptional regulatory function of an endogenous mutant p53 in MDA-468 human breast cancer cells. Biochem. Biophys. Res. Commun. 232, 14.

Shaulsky G, Ben-Zfiev A, Rotter V. (1990) Subcellular distribution of the p53 protein during the cell cycle of Balb/c 3T3 cells. Oncogene 5, 1707.

Slingerland JM, Jenkins JR, Benchimol S. (1993) The transforming and suppressor functions of p53 alleles: effects of mutations that disrupt phosphorylation, oligomerization and nuclear translocation. Embo. J. 12, 1029.

Steinmeyer K, Maacke H, Deppert W. (1990) Cell cycle control by p53 in normal (3T3) and chemically transformed (Meth A) mouse cells. I. Regulation of p53 expression. Oncogene 5, 1691.

Tsukada T, Tomooka Y, Takai $S$ et al. (1993) Enhanced proliferative potential in culture of cells from p53-deficient mice. Oncogene 8, 3313.

Ullrich SJ, Anderson CW, Mercer WE, Appella E. (1992) The p53 tumor suppressor protein, a modulator of cell proliferation. J. Biol. Chem. 267, 15259.

Ullrich SJ, Mercer WE, Appella E. (1992) Human wild-type p53 adopts a unique conformational and phosphorylation state in vivo during growth arrest of glioblastoma cells. Oncogene 7, 1635 .

Ullrich SJ, Sakaguchi K, Lees-Miller SP et al. (1993) Phosphorylation at Ser-15 and Ser-392 in mutant p53 molecules from human tumors is altered compared to wild-type p53. Proc. Natl. Acad. Sci. USA 90, 5954.

Wang NP, To H, LeE WH, LeE EY. (1993) Tumor suppressor activity of RB and p53 genes in human breast carcinoma cells. Oncogene 8, 279.

Zerrahn J, Deppert W, Weidemann D, Patschinsky T, Richards F, Miler J. (1992) Correiation between the conformational phenotype of p53 and its subcellular location. Oncogene 7, 1371. 